\title{
Evaluation of Temporal and Differential Fertilizer Application on Growth, Yield and Quality of Wheat
}

\author{
Raheela Naz ${ }^{1 *}$, Muhammad Aftab ${ }^{1}$, Ghulam Sarwar ${ }^{2}$, Ana Aslam ${ }^{1}$, Qudsia Nazir ${ }^{1}$, Asifa Naz ${ }^{3}$, Abid Niaz $^{4}$, \\ Farah Rasheed ${ }^{1}$, Amina Kalsom ${ }^{1}$, Nisa Mukhtar ${ }^{1}$, Sadia Sultana ${ }^{1}$, Ifra Saleem ${ }^{1}$, Arfan ul Haq ${ }^{1}$, Muhammad \\ Arif $^{1}$, Aamer Sattar $^{1}$, Sarfraz Hussain ${ }^{5}$ and Muhammad Adnan Rafique ${ }^{6}$
}

${ }^{1}$ Soil Chemistry Section, AARI, Faisalabad, Punjab, Pakistan; ${ }^{2}$ College of Agriculture, University of Sargodha, Punjab, Pakistan; ${ }^{3}$ Soil and Water Testing Laboratory, Khushab, Punjab, Pakistan; ${ }^{4}$ Provincial pesticide Reference laboratory, Raiywind, Lahore, Punjab, Pakistan; ${ }^{5}$ Institute of Soil Chemistry and Environmental Sciences, Kala Shah Kaku, Punjab, Pakistan; ${ }^{6}$ Pesticide Quality Control Laboratory, Kala Shah Kaku, Punjab, Pakistan.

Abstract | Pakistani soils are very poor in organic matter content; therefore, fertility status of soils is very low. Farmers apply fertilizer but below the recommended doses. As we know that for the better quality and yield of crops, time and method of fertilizers application are the most important factors. Some growth stages are very sensitive, at those stages of growth; the addition of fertilizers is more responsive than others. In order to nutrients to become available when the plant needs them and to make maximum benefits, fertilizers should be applied at the right time. In this experiment, impact of fertilizer applying methods for nitrogen and potash at different times was investigated on wheat crop. Wheat was sown as a test crop with six different fertilizer application methods at varying times under RCBD arrangement with three replications. The experimental soil was high in $\mathrm{pH}$, low in fertility status and free from salinity and sodicity hazards. Wheat grains were analyzed for mineral contents. The results revealed that maximum grain yield was obtained from treatment $\mathrm{T}_{6}$ (Half $\mathrm{N}$ at sowing time + spray of $2 \% \mathrm{~N}$ after $30 \& 45$ $\mathrm{DAS}+$ half $\mathrm{K}$ at sowing time + spray of $2 \% \mathrm{~K}$ after $30 \& 45 \mathrm{DAS})$ as compared to other treatments. Furthermore, the chemical analysis showed the maximum quantity of $\mathrm{N}, \mathrm{P}$ and $\mathrm{K}$ in wheat grains obtained from $\mathrm{T}_{6}$. This study concluded that split application of fertilizer at various stages of wheat crop produced better yield as well as wheat quality. The joined addition of NPK at sowing time along with $2 \%$ spray of $\mathrm{N}$ and $\mathrm{K}$ after 30 and 45 days of sowing is the best approach for the increase in wheat growth and yield.

Received | September 09, 2021; Accepted | January 14, 2022; Published | February 16, 2022

*Correspondence | Raheela Naz, Soil Chemistry Section, AARI, Faisalabad, Punjab, Pakistan; Email: raheela3046@gmail.com

Citation $\mid$ Naz, R., M. Aftab, G. Sarwar, A. Aslam, Q. Nazir, A. Naz, A. Niaz, F. Rasheed, A. Kalsom, N. Mukhtar, S. Sultana, I. Saleem, A.U. Haq, M. Arif, A. Sattar, S. Hussain and M.A. Rafique. 2022. Evaluation of temporal and differential fertilizer application on growth, yield and quality of wheat. Pakistan Journal of Agricultural Research, 35(1): 78-84.

DOI | https://dx.doi.org/10.17582/journal.pjar/2022/35.1.78.84

Keywords | Biomass, Fiber, Grain yield, Nutrients, Protein, Wheat

\section{Introduction}

$\mathrm{F}$ ood security is a global issue of developing world for the ever-increasing population, while the natural resources are the same. Healthy and nutrient enriched food through proper management practices of nutrients are necessary for a healthy generation and maintenance of successful life and social growth ( $\mathrm{Na}-$ zir et al., 2016). For healthy crops, different fertilizer application strategies are being used such as seed coating, soil application etc., while, foliar fertilization is considered better for the maximizing quality and yield of crops. The nutrients through this method are readily available to plant because it is independent of March 2022 | Volume 35 | Issue 1 | Page 78 
soil-water availability and root activity factors. In areas where saline and drought conditions prevail, the foliar application showed the best results as compared to soil application. In such situations, the required nutrients are rapidly absorbed because they are supplied to the leaves and absorbed directly. It has shown to be a good method for increasing N, P, K requirements for critical growth periods of a crop (Amanullah et al., 2013). A sufficient supply of nutrients is essential to obtain the maximum yield potential of crops.

Among all nutrients, nitrogen has prime importance to achieved successful plant growth of any crop because nitrogen is required for protein manufacturing that is an integral component of chloroplast and protoplast (Alam et al., 2010). In the soil, nitrogen is lost by many mechanisms including: denitrification, leaching, volatilization and runoff hence, nitrogen use efficiency reduces in the rhizosphere (Qadri et al., 2015).

The importance of potassium $(\mathrm{K})$ in plants is well documented, it is involved in enzyme activation (Abid et al., 2016), various metabolic activities in plants such as cation-anion balance, stomatal conductance, photosynthesis, energy transfer, osmoregulation, phloem transport, protein synthesis, carbohydrate translocation in plants and meristematic growth etc. It is well known fact that potassium is famous for its impacts on metabolism of vitamins, formation of nucleic acids, generation of many substances essential for plant development as well as synthesis of proteins. It is known as a key active cation of the plant cell. It also enables the plant to resist against pests and diseases, and also improves the synthesis of fats and carbohydrates. In the growth and development of plants as well as many growth regulating mechanisms within the plant, role of potassium is self-explanatory (Bukhsh et al., 2012). Potassium has major part in refining plant acceptance under anxiety circumstances (Khan et al., 2014). K is tangled in meristematic tissue's development, cell turgor pressure, quality determination and crop productivity (Gul et al., 2011; Dewdar and Rady, 2013).

Foliar applied fertilizers, alone or in combination with pesticides reduced the environmental threat of pollution by decreasing the amount of nutrients and increasing the economic effects of nutrients (Kalinova et al., 2014). When soil moisture is limited then foliar application of $\mathrm{N}$ is useful for improving grains protein and plant productivity. Plant's lodging risk can also be reduced by the late addition of $\mathrm{N}$ in foliar mode. However, weight per grain was increased by its application during and after the anthesis stage (Woolfolk et al., 2002). In some cases, foliar applied nitrogen showed a better response than granular applied nitrogen. In wheat crop, foliar $\mathrm{N}$ application during anthesis and milking stage increased grain protein. After the late milky-ripe stage, foliar applied $\mathrm{N}$ is not taken up by plant. At these timings, carbohydrate accumulation is reduced and ultimately plants show no response in terms of yield (Baloch et al., 2019).

Combine usage of fertilizers in foliar and soil mode has been evaluated better to enhance growth components and maize grain yield (Asumadu et al., 2012). Foliar usage of nutrients surges vegetative as well as crop attributes of wheat in comparison to soil addition. Because of interfering of many edaphic factors like loss of nutrients due to leaching, deficiency of soil water and less temperature in the soil, roots are incapable of nutrient absorption. In such situations, foliar application is very useful (Rahman et al., 2014). In most cases, foliar feeding is less costly and more effective, and gives better response than soil application (Jamal et al., 2006). Keeping in view the low fertility status of Pakistani soils and low fertilizer use efficiency, current trial was performed to evaluate the impacts of temporal and fertilizer usage on various wheat parameters like crop quality and development.

\section{Materials and Methods}

This research experiment was done at AARI, Faisalabad, Punjab, Pakistan during 2017-2019. Wheat seeds were sown in the soil on November 20, 2017 and crop after maturity was harvested in April 24, 2018 for the first time and this same practice was followed for $2^{\text {nd }}$ year of experimentation.

\section{Experiment Setup, Treatments and Measurements}

Soil samples were collected for determination of different characteristics (physical and chemical) before starting this trial.

Six treatments with three replications were tested by using RCBD design of statistics. Experiment comprised of the following treatments:

$\mathrm{T}_{1}=\mathrm{N}, \mathrm{P}$ AND $\mathrm{K}$ as recommended dose (RD).

$\mathrm{T}_{2}=\mathrm{K}$ as $\mathrm{RD}+$ half $\mathrm{N}$ at sowing time + spray of $2 \%$ $\mathrm{N}$ after 30 \& 45 DAS.

$\mathrm{T}_{3}=\mathrm{N}$ as $\mathrm{RD}+$ half $\mathrm{K}$ at sowing time + half $\mathrm{K}$ after 
30 DAS.

$\mathrm{T}_{4}=\mathrm{N}$ as $\mathrm{RD}+$ half $\mathrm{K}$ at sowing time + spray of $2 \%$ $\mathrm{N}$ after 30 \& 45 DAS.

$\mathrm{T}_{5}=$ Half $\mathrm{N}$ at sowing time + spray of $2 \% \mathrm{~N}$ after $30 \& 45$ DAS + half $\mathrm{K}$ at sowing time + half $\mathrm{K}$ after 30 DAS.

$\mathrm{T}_{6}=$ Half $\mathrm{N}$ at sowing time + spray of $2 \% \mathrm{~N}$ after $30 \& 45$ DAS + half K at sowing time + spray of $2 \% \mathrm{~K}$ after $30 \& 45 \mathrm{DAS}$.

Urea, SSP and $\mathrm{K}_{2} \mathrm{SO}_{4}$ remained respective sources for $\mathrm{N}, \mathrm{P}$ and $\mathrm{K}$ and were applied to all pots as per treatment plant. These fertilizers were added at the rate of $120 \mathrm{~N}-90 \mathrm{P}-60 \mathrm{~K}$ for $\mathrm{kg} / \mathrm{h}$. These fertilizers were applied to all plots as per action proposal. Wheat variety Faisalabad-2008 was sown. All agronomic practices were carried out for optimum growth and yield of wheat. Soil samples were examined for different properties i.e., EC and $\mathrm{pH}$ (Richards, 1954), and organic matter (Walkley, 1947). Fertility status of soil was determined by measuring extractable K (Richards, 1954) and Olsen P (Olsen, 1954). Hydrometer method was used for textural class determination (Bouyoucos, 1962). Wheat grain and straw yield were measured along with other growth parameters.

\section{Chemical analysis of grains}

Grain samples were taken at harvesting and oven dried at $70^{\circ} \mathrm{C}$, ground, digested and analyzed for concentration of nitrogen, phosphorus and potassium. Digestion of these samples was done in tri-acid mixture of $\mathrm{H}_{2} \mathrm{SO}_{4}-\mathrm{HClO}_{4}-\mathrm{HNO}_{3}$ (George et al., 2013). Metavanadate colour method was applied for P-estimation (Jackson, 1979) with Spectrophotometer IRMECO model U-2020, whereas flame spectrophotometry method was used for potassium determination in plant samples (Chapman and Pratt, 1961). $\mathrm{N}$ was analyzed by applying protocols of Bremner (1996). The quality parameter i.e., crude protein remained estimated by multiplying $\mathrm{N}$ concentration by 6.25 (Fujihara et al., 2008).

\section{Statistical analysis}

Entirely composed data were exposed to analysis of statistics using RCBD. Mean comparison was carried out according to the LSD test, at $\mathrm{p} \leq 0.05$ probability level (Steel et al., 1997).

\section{Results and Discussion}

Basic soil analysis indicated that the experimental site had sandy clay loam texture and free from salinity and sodicity, low in organic matter and available phosphorus while sufficient in available potassium. The chemical analysis of the experimental soil is mentioned in Table 1.

Table 1: Soil physico-chemical properties before experimentation.

\begin{tabular}{llllll} 
Parameters & Units & \multicolumn{5}{c}{ Depth (cm) } \\
& & $\mathbf{0 - 1 5}$ & $\mathbf{1 5 - 3 0}$ & $\mathbf{0 - 1 5}$ & $\mathbf{1 5 - 3 0}$ \\
& & $\mathbf{2 0 1 8}$ & & $\mathbf{2 0 1 9}$ & \\
EC & $\mathrm{dS} \mathrm{m}^{-1}$ & 1.11 & 1.00 & 1.31 & 1.11 \\
$\mathrm{pH}$ & - & 7.62 & 6.65 & 7.53 & 7.66 \\
Organic Matter (OM) & $\%$ & 0.99 & 0.68 & 0.75 & 0.43 \\
Available P & $\mathrm{ppm}$ & 7.6 & 5.4 & 6.9 & 4.3 \\
Available K & $\mathrm{ppm}$ & 188 & 149 & 116 & 68 \\
Texture & & \multicolumn{5}{c}{ Sandy clay loam }
\end{tabular}

Table 2: Various yield parameters as affected by $N$ and $K$ application through different modes.

$\begin{array}{lllllll}\begin{array}{l}\text { Treat- Plant } \\ \text { ments }\end{array} & \begin{array}{l}\text { height } \\ \text { (cm) }\end{array} & \begin{array}{l}\text { Number tillers/ } \\ \text { plant }\end{array} & \begin{array}{l}\text { Num- } \\ \text { ber of } \\ \text { spikes/ } \\ \text { plant }\end{array} & \begin{array}{l}\text { Num- } \\ \text { ber of } \\ \text { spikelet/ } \\ \text { spike }\end{array} & \begin{array}{l}\text { Grain/ } \\ \text { spike }\end{array} & \begin{array}{l}\text { 1000- } \\ \text { grain } \\ \text { weight } \\ \text { (g) }\end{array} \\ \mathrm{T}_{1} & 98 \mathrm{~b} & 11 \mathrm{a} & 10 \mathrm{a} & 19 \mathrm{a} & 57 \mathrm{ab} & 41.00 \mathrm{ab} \\ \mathrm{T}_{2} & 103 \mathrm{ab} & 9 \mathrm{bc} & 9 \mathrm{a} & 20 \mathrm{a} & 57 \mathrm{ab} & 44.33 \mathrm{a} \\ \mathrm{T}_{3} & 104 \mathrm{ab} & 9 \mathrm{bc} & 9 \mathrm{a} & 19 \mathrm{a} & 53 \mathrm{ab} & 39.33 \mathrm{~b} \\ \mathrm{~T}_{4} & 105 \mathrm{a} & 10 \mathrm{~b} & 9 \mathrm{a} & 20 \mathrm{a} & 54 \mathrm{ab} & 40.33 \mathrm{~b} \\ \mathrm{~T}_{5} & 104 \mathrm{ab} & 7 \mathrm{~d} & 7 \mathrm{~b} & 19 \mathrm{a} & 65 \mathrm{a} & 42.67 \mathrm{ab} \\ \mathrm{T} 6 & 100 \mathrm{ab} & 9 \mathrm{c} & 9 \mathrm{a} & 19 \mathrm{a} & 48 \mathrm{~b} & 42.67 \mathrm{ab} \\ \mathrm{LSD} & 5.83 & 1.00 & 1.96 & 1.45 & 14.09 & 3.78\end{array}$

All the values are means of triplicates $\pm S D$. Letters in a column are not significantly $(p \leq 0.05)$ dissimilar rendering to Fishers least significant difference (LSD).

\section{Wheat growth attributes}

The results showed that split application of fertilizer, significantly increased the plant height and maximum plant height $(105 \mathrm{~cm})$ was recorded in treatment where $\mathrm{RD}$ of $\mathrm{N}+1 / 2 \mathrm{~K}$ at sowing $+2 \%$ spray of $\mathrm{K}$ at 30 and $45 \mathrm{DAS}$ were applied, while, minimum plant height $(98 \mathrm{~cm})$ was observed in $\mathrm{T}_{1}$ where $\mathrm{RD}$ of $\mathrm{N}, \mathrm{P}$ and $\mathrm{K}$ was applied while other treatments were statistically remained at par (Table 2). Maximum number of tillers (11 tillers/plant) was obtained in $\mathrm{T}_{1}$ where $\mathrm{RD}$ of $\mathrm{N}, \mathrm{P}$ and $\mathrm{K}$ was applied followed by $\mathrm{T}_{4}$ (10 tiller/plant) where $\mathrm{RD}$ of $\mathrm{N}+1 / 2 \mathrm{~K}$ at sowing $+2 \%$ spray of $\mathrm{K}$ at 30 and 45 DAS was applied. Minimum number of spikes/plant (7) was found in $\mathrm{T}_{5}$ treatment while all other treatments were statis- 
tically at par with each other. Non-significant effect of all treatments was observed in the case of number of spikelets /spike. The number of grains/spike is also significant parameter to predict the yield of wheat grain. The highest number of grains/spike (65) was found in treatment $\mathrm{T}_{5}$ where $1 / 2 \mathrm{~N}$ at sowing $+2 \%$ spray of $\mathrm{N}$ at 30 and $45 \mathrm{DAS}+1 / 2 \mathrm{~K}$ at sowing $+1 / 2$ $\mathrm{K}$ at $30 \mathrm{DAS}$ were applied. On the other hand, maximum 1000 grain weight (44.33 g) was found in $\mathrm{T}_{2}$ treatment followed by $\mathrm{T}_{5}$ and $\mathrm{T}_{6}$ treatment $(42.67 \mathrm{~g})$.

\section{Wheat yield attributes}

Two years data (Figure 1) showed that soil and foliar applied $\mathrm{N}$ and $\mathrm{K}$ (urea and $\mathrm{K}_{2} \mathrm{SO}_{4}$ ) significantly affect grain yield of wheat. The maximum grain yield was recorded from $\mathrm{T}_{4}\left(4.11\right.$ tons $\left.\mathrm{ha}^{-1}\right)$ and $\mathrm{T}_{6}$ (3.88 tons $\left.\mathrm{ha}^{-1}\right)$ treatments respectively. However, both treatments showed statistically non-significant results. Higher straw yield 7.08 tons $\mathrm{ha}^{-1}$ and 7.09 tons $\mathrm{ha}^{-1}$ was recorded in $\mathrm{T}_{1}$ and $\mathrm{T}_{3}$ (Figure 2).

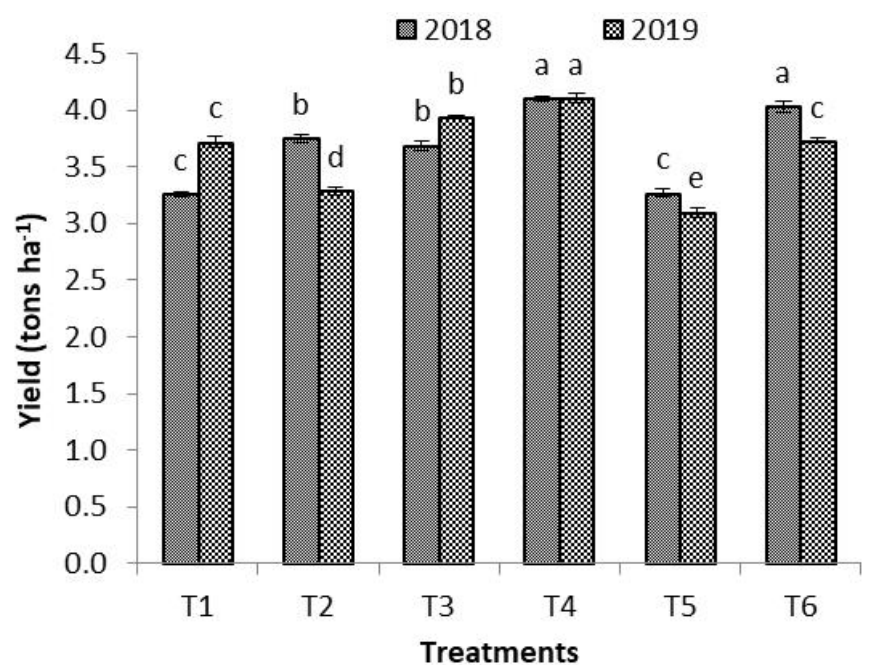

Figure 1: Wheat yield as affected by $N$ and $K$ application through different modes.

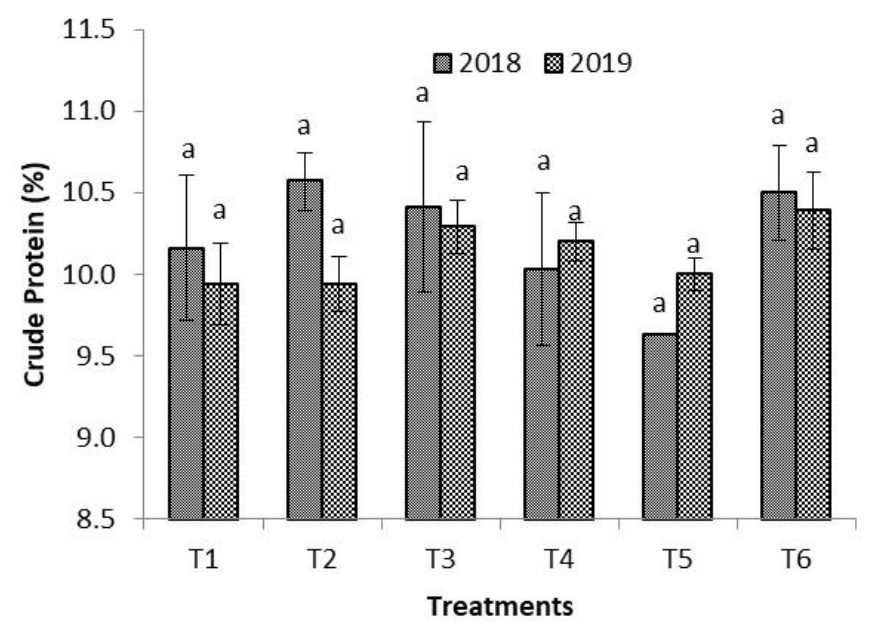

Figure 2: Wheat straw yield as affected by $N$ and $K$ application through different modes.
Quality parameters

Data related to quality parameters were given in Figure 3 and 4. During year 2018-2019 maximum crude protein $(10.45 \%)$ was found in treatment $\mathrm{T}_{6}$ and minimum was found in treatment $T_{5}$. Maximum crude fiber was found in treatment $T_{1}$ where recommended NPK was applied, while all other treatments were at par with each other.

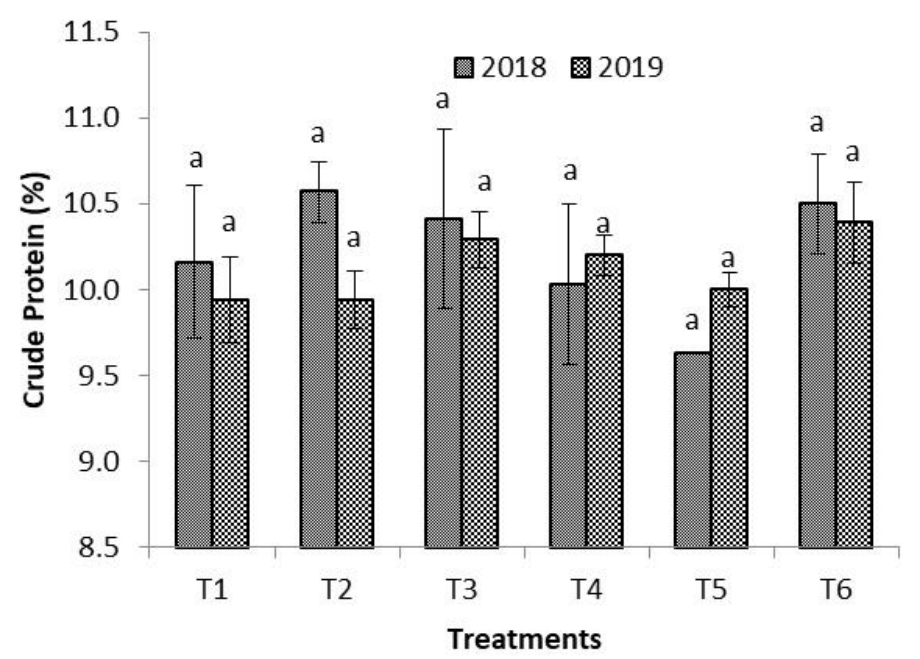

Figure 3: Crude Protein as affected by $N$ and $K$ application through different modes.

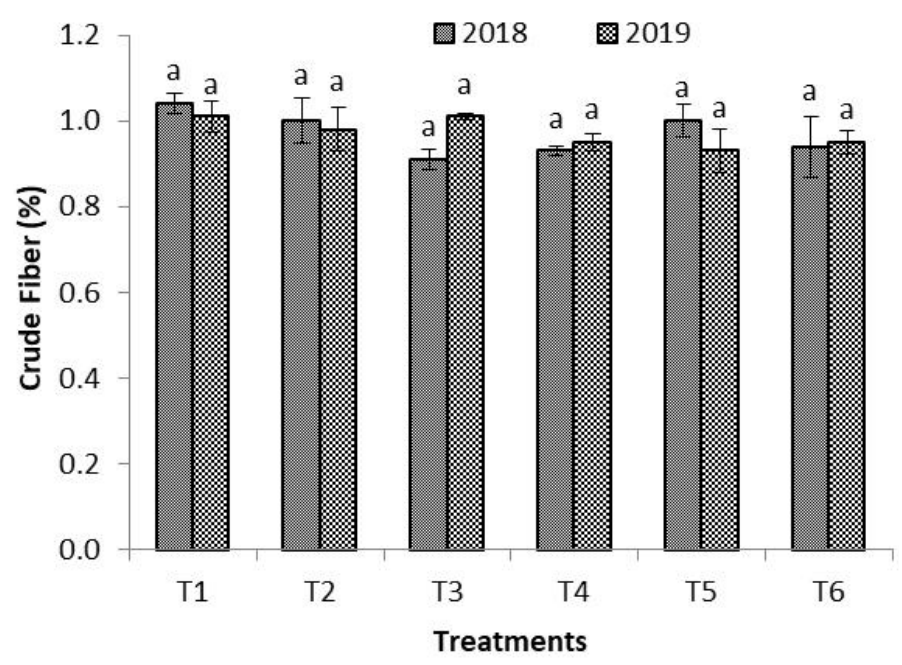

Figure 4: Crude Fiber as affected by $N$ and $K$ application through different modes.

\section{Nutrient concentration in wheat grains}

The N, P and $\mathrm{K}$ concentration were evaluated and results presented in Table 3 . The nitrogen contents in grain showed that all treatments were statistically similar. On the other hand, maximum phosphorus content was observed in $\mathrm{T}_{4}$, while the maximum $\mathrm{K}$ was observed in $\mathrm{T}_{6}$, which were 92 and $74 \%$ increase respectively as compared to their respective controls.

Kenbaev and Sade (2002) reported that foliar spray of 
nutrients in combination or alone enhance the plant height. Previous studies also indicated that foliar application of potassium improves plant height in wheat when sprayed under drought conditions at vegetative stage than at flowering or at grain filling stages (Aown et al., 2012). Arif et al. (2010) reported that increased number of tillers was observed due to foliar application of $\mathrm{K}$. The number of grains/spikes is also significant parameter to predict the yield of wheat grain. Parvez et al. (2009) described that number of grains/spike was significantly increased with foliar spray of urea. Guenis et al. (2003) and Soylu et al. (2005) reported that 1000 grain weight was significantly improved with nutrient foliar application. Foliar and soil applied $\mathrm{N}$ and $\mathrm{P}$ also improved the grain yield of wheat. Arif et al. (2009) described that foliar applied $\mathrm{N}$ ensures the sufficient availability of nutrients to crops for obtaining higher yield. Another study indicated that potato yield was also improved by $\mathrm{K}$ sprays on weekly basis (Fageria et al., 2009). Foliar spray $1.5 \% \mathrm{~K}_{2} \mathrm{SO}_{4}$ improved straw and paddy yield as compared to $\mathrm{KCl}$ and $\mathrm{KNO}_{3}$ (Ali et al., 2005). This might be due to suitable concentration of $\mathrm{K}_{2} \mathrm{SO}_{4}$ for foliar application which produced high yield. Maize grain yield was much improved by urea spray of $7 \mathrm{~kg} \mathrm{~N} \mathrm{ha-1}$. Plants cannot consume urea $\mathrm{N}$ when its foliar application was done after anthesis stage because it prolongs the dry matter accumulation in plants (Singh, 2003). John and Lester (2011) described that foliar applied potassium increased crude protein in grains due to the better accessibility of nutrients to cereals. Dekov (2004) described that nitrogen spray after flowering stage increased the seed protein.

Table 3: Nutrient contents of wheat grains as affected by $N$ and $K$ application through different modes.

$\begin{array}{llll}\text { Treatments } & \mathbf{N}(\%) & \mathbf{P ( \% )} & \mathbf{K}(\%) \\ \mathrm{T}_{1} & 1.62 \mathrm{a} & 0.38 \mathrm{ab} & 0.46 \mathrm{c} \\ \mathrm{T}_{2} & 1.69 \mathrm{a} & 0.40 \mathrm{ab} & 0.54 \mathrm{abc} \\ \mathrm{T}_{3} & 1.66 \mathrm{a} & 0.40 \mathrm{ab} & 0.49 \mathrm{bc} \\ \mathrm{T}_{4} & 1.61 \mathrm{a} & 0.42 \mathrm{a} & 0.48 \mathrm{bc} \\ \mathrm{T}_{5} & 1.54 \mathrm{a} & 0.38 \mathrm{ab} & 0.57 \mathrm{ab} \\ \mathrm{T}_{6} & 1.68 \mathrm{a} & 0.38 \mathrm{~b} & 0.62 \mathrm{a} \\ \mathrm{LSD} & 0.15 & 0.04 & 0.10\end{array}$

All the values are means of triplicates $\pm S D$. Letters in a column are not significantly $(p \leq 0.05)$ dissimilar rendering to Fishers least significant difference (LSD)

\section{Conclusions and Recommendations}

This study concluded that split and foliar application of $\mathrm{N}$ and $\mathrm{K}$ improved the plant height, grain yield and straw yield. The N, P and $\mathrm{K}$ contents of wheat grain also increased by split and foliar application while quality parameters (protein and crude fiber) remained unaffected.

\section{Acknowledgements}

I acknowledge Institute of Soil Chemistry and Environmental Sciences, AARI, Faisalabad-Pakistan to provide facilities to do this research.

\section{Novelty Statement}

Wheat growth and yield was improved by $\mathrm{N}$ and $\mathrm{K}$ application through split and foliar mode.

\section{Author's Contribution}

Raheela Naz: Basic Researcher.

Ana Aslam, Qudsia Nazir and Asifa Naz: Preparation of graphs on excel.

Abid Niaz: Complete direction, supervision of paper preparation.

Sarfraz Hussain and Ghulam Sarwar: Proof read and edited for English language.

Farah Rasheed, Amina Kalsom and Nisa Mukhtar: Contributed in laboratory analysis.

Sadia Sultana and Ifra Saleem: Elaborated results and discussion.

Muhammad Aftab and Arfan ul Haq: Participated in materials and methodology portion.

Muhammad Arif and Muhammad Adnan Rafique: Contributed to introduction section.

Aamer Sattar: Analysis of research data for statistics.

Conflict of interest

Authors declare that they have no conflict of interest.

\section{References}

Abid, A., M. Hussain, H.S. Habib, T.T. Kiani, M.A. Anees and M.A. Rahman. 2016. To evaluate the better response of foliar spray over soil application of potassium on hybrid maize yield under rainfed conditions. Turk. J. Field Crops, 21(1):36-43. https://doi.org/10.17557/ tjfc.66054

Alam, S.S., A.Z.M. Moslehuddin, M.R. Islam and A.M. Kamal. 2010. Soil and foliar application of nitrogen for Boro rice (BRRIdhan 29). J. Bangladesh Agric. Univ., 8(2):199-202. https:// 
doi.org/10.3329/jbau.v8i2.7925

Ali, A., M. Salim, M.S. Zia, I.A. Mahmood and A. Shahzad. 2005. Performance of rice as effected by foliar application of different $\mathrm{K}$ fertilizer sources. Pak. J. Agric. Sci., 42(1-2):38-41.

Amanullah, A.Z. Khan, A. Jan, Z. Shah, B. Ahmad, S.K. Khalil, A. Ali, Hidayyatullah, F. Ahmad and A. Nawaz. 2013. Foliar application of nitrogen at different growth stages influences the phenology, growth and yield of maize (Zea mays L.). Soil Environ., 32 (2):135-140.

Aown, M., S. Raza, M.F. Saleem, S.A. Anjum, T. Khaliq and M.A. Wahid. 2012. Foliar application of potassium under water deficit conditions improved the growth and yield of wheat. J. Anim. Plant Sci., 22(2):431-437.

Arif, M., M.A. Chohan, S. Ali, R. Gul and S. Khan. 2009. Response of wheat to foliar application of nutrients. J. Agric. Biol Sci., 1(4):30-34.

Arif, M., M. Arshad, H.N. Asghar and S.M.A. Basra. 2010. Response of rice (Oryza sativa) genotypes varying in $\mathrm{K}$ use efficiency to various levels of potassium. Int. J. Agric. Biol., 12(6):926-930.

Asumadu, H. and H.K. Adu-Dapaah. 2012. Response of maize to organic foliar fertilizer and its economic implications to farmers in Ghana. Int.J.Agric. Res., 7(9):439-448. https:// doi.org/10.3923/ijar.2012.439.448

Baloch, N., M. Buriro, G.H. Jatoi, K.A. Memon, S.A. Nahiyoon, P. Hou, P. and S. Li. 2019. Effect of foliar application of nitrogen on growth, yield and grain quality parameters of wheat (Triticum aestivum L.). Biocell., 43(5):261-267.

Bremner, J.N. 1996. Nitrogen-total. In: Method in soil analysis, part 3 Chemical methods. Soil Sci. Soc. Am., Am. Soc. Agron. pp. 1085-1121. https://doi.org/10.2136/sssabookser5.3.c37

Bouyoucos, G.J. 1962. Hydrometer method improved for making particle size analysis of soil. Agron., 54(5):464-465. https://doi. org/10.2134/agronj1962.00021962005400050 028x

Bukhsh, M., R. Ahmad, J. Iqbal, M.M. Maqbool, A. Ali, M. Ishaque and S. Hussain. 2012. Nutritional and physiological significance of potassium application in maize hybrid crop production. Pak. J. Nutr., 11(2):187-202. https://doi.org/10.3923/pjn.2012.187.202

Chapman, H.D. and P.F. Pratt. 1961. Methods of analysis for soils, plants, and waters. Riverside,
California. https://doi.org/10.1097/00010694196201000-00015

Dekov, D. 2004. Effect of late foliar application of nitrogen on grain yield and quality of soft and durum wheats. Rasteniev dni-Nauki, 25(7):1723.

Dewdar, M.D.H. and M.M. Rady. 2013. Influence of soil and foliar applications of potassium fertilization on growth, yield and fiber quality traits in two Gossypium barbadense L. varieties. Afr. J. Agric. Res., 8(19):2211-2215. https:// doi.org/10.5897/AJAR12.1861

Fageria, N.K., M.B. Filho, A. Moreira and C.M. Guimarães. 2009. Foliar fertilization of crop plants. J. Plant Nutr., 32(6):1044-1064. https:// doi.org/10.1080/01904160902872826

Fujihara, S., H. Sasaki, Y. Aoyagi and T. Sugahara. 2008. Nitrogen-to-protein conversion factors for some cereal products in Japan. J. Food Sci., 73(3):204-209. https://doi.org/10.1111/ j.1750-3841.2008.00665.x

George, E., S. Rolf and R. John. 2013. Methods of soil, plant, and water analysis. A manual for the West Asia and North Africa region. International Center for Agricultural Research in the Dry Areas (ICARDA), 244p.

Guenis, A., M. Alpaslan and A. Unal. 2003. Effects of boron fertilization on the yield and some yield components of bread and durum wheat. Turk. J. Agric., 27(6):329-335.

Gul, H., A. Said, B. Saeed and F. Mohammad. 2011. Effect of foliar application of nitrogen, potassium and zinc on wheat growth. ARPN J. Agric., 6(4):56-59.

Jackson, M.L. 1979. Soil chemical analysis: Advanced course, $2^{\text {nd }}$ edn. Department of Soil Science, University of Wisconsin, Madison, USA.

Jamal, Z., M. Hamayum, N. Ahmad, and M.F. Chaudhary. 2006. Effect of soil and foliar application of different concentrations of NPK and foliar application of $\left(\mathrm{NH}_{4}\right)_{2} \mathrm{SO}_{4}$ on different yield parameters in wheat. J. Agron., 5(2):251256. https://doi.org/10.3923/ja.2006.251.256

John, L.J. and G.E. Lester. 2011. Effect of foliar potassium fertilization and source on cantaloupe yield and quality. Better Crops, 95(1):13-15.

Kalinova, S., S. Kostadinova and A. Hristoskov. 2014. Nitrogen use efficiency and maize yield response to nitrogen rate and foliar fertilizing. Bulg. J. Agric. Sci., 20(1):178-181. 
Kenbaev, B. and B. Sade. 2002. Response of fieldgrown barley cultivars grown on zinc-deficient soil to zinc application. Commun. Soil Sci. Plant Anal., 33(3-4):533-544. https://doi. org/10.1081/CSS-120002762

Khan, A.A., Inamullah and T.M. Jan. 2014. Impact of various nitrogen and potassium levels and application Methods on grain yield and yield attributes of wheat. Sarhad J. Agric., 30(1):3546.

Nazir, Q. A. Hussain, M. Imran, S. Mahmood, M. Ahmad and M.M. Iqbal. 2016. Zinc biofortification of cereals through fertilizers: Recent advances and future perspectives. Asian J. Agric. Biol., 4(4):140-152.

Parvez, K., M.Y. Memon, M. Imtiaz and M. Aslam. 2009. Response of wheat to foliar and soil application of urea at different growth stages. Pak. J. Bot., 41(3): 1197-1204.

Olsen, S.R. 1954. Estimation of available phosphorus in soils by extraction with sodium bicarbonate. US Department of Agriculture.

Qadri, R.W.K., I. Khan, M.M. Jahangir, U, Ashraf, G. Samin, A, Anwer, M. Adnan and M. Bashir. 2015. Phosphorus and foliar applied nitrogen improved productivity and quality of potato. Am. J. Plant Sci., 6(1):144-149. https://doi. org/10.4236/ajps.2015.61016

Rahman, I.U., A. Afzal, Z. Iqbal, S. Manan. 2014. Foliar Application of Plant Mineral Nutrients on Wheat: A Review. Research and Reviews: J.
Agric. Appl. Sci., 3:19-22.

Richards, L. 1954. Diagnosis and improvement of saline and alkali soils. USDA Hand Book. No. 60. US Govt. Press, Washington, DC. https:// doi.org/10.1097/00010694-195408000-00012

Singh, B.R. 2003. Sulfur and crop quality agronomical strategies for crop improvement. Abstracts of COST Action 829 meetings, Braunschweig, Germany.

Soylu, S., B. Sade, A.Topal, N. Akgun and S. Gezgin. 2005. Responses of irrigated durum and bread wheat cultivars to boron application in low boron calcareous soil. Turk. J. Agric., 29(4):275-286.

Steel, R.G.D., J.H. Torrie and D.A. Dicky. 1997. Principles and procedures of statistics. A Biometrical Approach: p. 204-227. McGraw Hill Book International Co., Singapore.

Woolfolk, C.W., W.R. Raun, G.V., Johnson, W.E., Thomason, R.W., Mullen, K.J., Wynn, and K.W., Freeman. 2002. Influence of late-season foliar nitrogen applications on yield and grain nitrogen in winter wheat. Agron. J., 94(3):429434. https://doi.org/10.2134/agronj2002.4290

Walkley, A., 1947. A critical examination of a rapid method for determining soil organic carbon in soils-effect of variations in digestion conditions and inorganic soil constituents. J. Soil Sci., 63(4):251-263. https://doi. org/10.1097/00010694-194704000-00001 